\title{
Evaluation of the individual, environmental and educational cognitive impact factors on the quality of clinical medical education from the viewpoint of clinical professors and students in Ramsar - Mazandaran University Campus of Medical Sciences
}

\author{
Ali Siahposht Khachaki ${ }^{*}$ (iD, Erfan Ghadirzadeh ${ }^{2}$, Hossein Firouzi ${ }^{3}$, Fatemeh Hosseinzadeh Dogolsar ${ }^{4}$, \\ Alimorad Heydari Gorgi5 ${ }^{5}$ Mobin Bararpoor ${ }^{6}$ \\ 1. Assistant Professor of Physiology, Director of Education Development Office of Ramsar Campus, Mazandaran University of Medical \\ Sciences, Ramsar, Iran \\ 2. Medical Student, Student Research Committee, Mazandaran University of Medical Sciences, Sari, Iran \\ 3. Assistant Professor of Neonatal-Perinatal Medicine, Mazandaran University of Medical Sciences, Ramsar, Iran \\ 4. Expert in Education Development Office, Mazandaran University of Medical Sciences, Ramsar, Iran \\ 5. Assistant Professor of Healthcare Services Management, Mazandaran University of Medical Sciences, Ramsar, Iran \\ 6. Medical Student, Student Research Committee, Mazandaran University of Medical Sciences, Ramsar, Iran
}

Recieved: 10 Jan. 2020

Revised: 20 Apr. 2020

Accepted: 13 May. 2020

\section{Keywords}

Clinical-education

Cognitive

Individual facrors

Environmental facrors

Educational facrors

\section{Corresponding author}

Ali Siahposht Khachaki, Assistant Professor of Physiology, Director of Education Development Office of Ramsar Campus, Mazandaran University of Medical Sciences, Ramsar, Iran

Email: A.siahposht@mazums.ac.ir

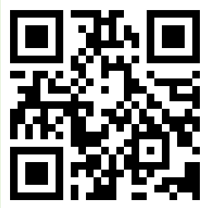

doi.org/10.30699/icss.22.2.63

\section{Abstract}

Introduction: Clinical education plays a fundamental role in shaping medical students' basic skills and professional abilities, so understanding its current status can help us provide a platform for improving their performance in the future. The present study was conducted to identify the cognitive factors affecting clinical education quality at the Ramsar campus. Methods: The present research was a cross-sectional descriptive study of 181 cases in 2019. Sampling was performed by census method. Data were collected by a researcher-made questionnaire that included demographic information plus students' and professors' viewpoints on clinical education. Collected data were analyzed using descriptive statistics, chi-square and independent t-test in SPSS-18.

Results: In this study, $69.23 \%$ of the students were female and $46 \%$ of the professors were male. Also, $80 \%$ of teachers and $50.64 \%$ were married. There was a significant relationship between the test's assumptions, which includes the individual characteristics of the subject, the individual characteristics of the teacher, the clinical environment, educational planning, and the clinical evaluation variable $(\mathrm{P}<0.05)$.

Conclusion: According to the findings, accurate and concise implementation of the existing curriculum, providing an appropriate educational environment and awaking professors, and hospital personnel about their responsibility regarding students and their duties can improve the quality of clinical education.

Citation: Siahposht Khachaki A, Ghadirzadeh E, Firouzi H, Hosseinzadeh Dogolsar F, Heydari Gorgi A, Bararpoor M. Evaluation of the individual, environmental and educational cognitive impact factors on the quality of clinical medical education from the viewpoint of clinical professors and students in Ramsar - Mazandaran University Campus of Medical Sciences. Advances in Cognitive Sciences. 2020;22(2):63-70. 
())

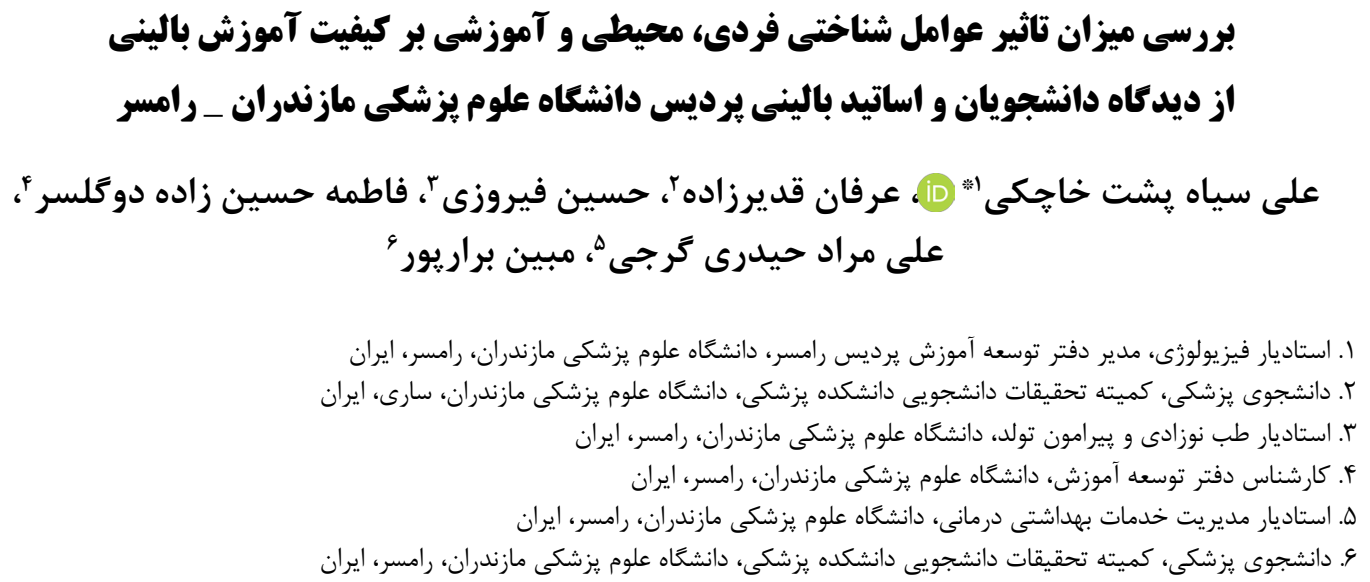

\section{ars}

مقلدمهه: آموزش بالينى در شكل دهى مهارتهاى اساسى و توانمندى هاى حرفهاى دانشجويان يزشكى نقش اساسى دارد. بنابراين شناخت وضعيت فعلى آن مىتواند بسترى براى ارتقاء وضعيت عملكرد آنها در آينده فراهم سازد. با توجه به اين امر، مطالعه حاضر با هدف شناسايى عوامل شناختى موثر بر كيفيت آموزش بالينى در يرديس رامسر انجام يذيرفت. روش كار: مطالعه حاضر توصيفى_مقطعى بود. ال1 نفر از دانشجويان و اساتيد بالينى يرديس رامسر در سال Vوسا به روش نمونه گيرى سرشمارى وارد مطالعه شدند. ابزار گردآورى دادها برسشنامه محقق ساخته بود كه شامل دو قسمت اطلاعات جمعيتشناختى، ديدگاه دانشجويان و اساتيد بالينى درباره آموزش بالينى بود. دادها با استفاده از آزمون كاى_دو و آزمون t مستقل به وسيله نرمافزار SPSS-18 مورد تجزيه و تحليل قرار كرفتند.

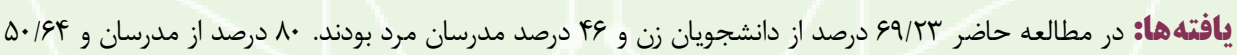
درصد از دانشجويان متاهل بودند. نتايج نشان داد ارتباط معنادارى ميان حيطههاى آزمون كه شامل خصوصيات فردى فراكير، خصوصيات فردى مدرس، محيط بالينى، برنامهريزى آموزشى و متغير ارزشيابى بالينى وجود داشت (ه•/P<). نتيجه كَيرى: بر اساس نتايج مطالعه جنين به نظر مىرسد كه با تقويت و اجراى دقيق و منظه برنامهاى موجود، بهبود فضاى آموزشى و آشنا نمودن مربيان با شح وظايف خود در قبال دانشجويان مى توان كيفيت آموزش بالينى را ارتقا داد.

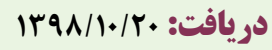

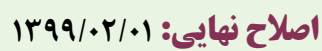

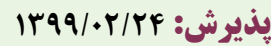

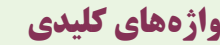
كيفيت آموزش بالينى دانشجويان

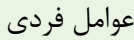
عوامل محيطى عوامل آموزشى مئى

نويسنله مسئول

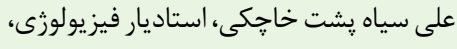

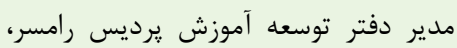
دانشكاه علوم يزشكى مازندران، رامسر، ايران

ايميل:A.siahposht@mazums.ac.ir

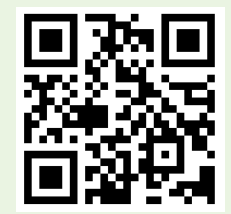

dol doi.org/10.30699/icss.22.2.63

مقدمه

(ץ). دانشجويان به منظور داشتن حداكثر كارايى در كلاسهاى عملى دانش مورد نيازشان را در كلاسهاى تئورى كسب نموده و از طريق تجربه در محيطهاى بالينى توانمندى عملى لازم را كسب مى كنند. مفهوم واقعى آموزش در بالين يعنى ايجاد بستر لازم براى همسو كردن اطلاعات علمى يايه دانشجو با انجام مهارتها همراه با تشخيص، درمان
دانشعاه ها موظف به تربيت دانشجويانى هستند كه توانايى كافى براى ييشخيرى، درمان و ارتقاى بهداشت در جامعه داشته باشند ( (1). با توجه به نقش مهم :يزشكان به عنوان عضوى موثر در ارائه خدمات اجتماعى و تاكيد بر آموزش اين افراد، لزوم وجود نظام منظم علمى و حرفهاى دانشگاه به عنوان بستر واقعى تربيت نيروى انسانى غيرقابل انكار است 
علمى و مدرسان بالينى) همواره در دسترس بودند و همجنين به جهت افزايش صحت و دقت كسب اطلاعات، همه افراد جامعه وارد مطالعه

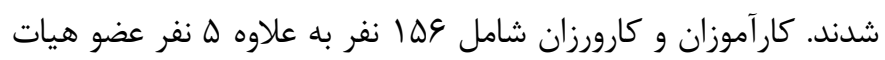

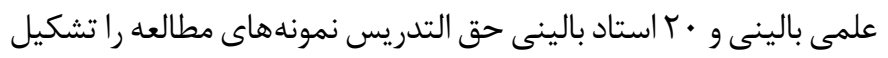

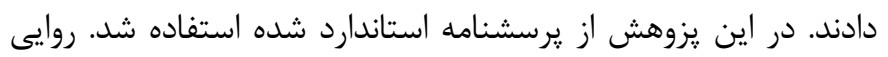

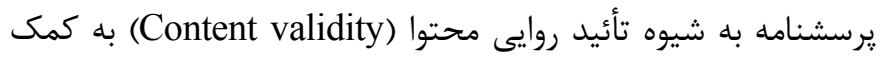

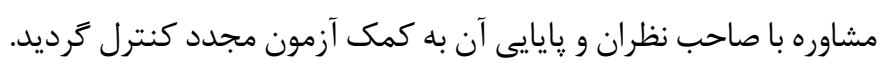

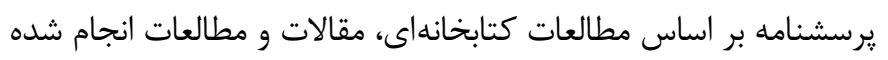

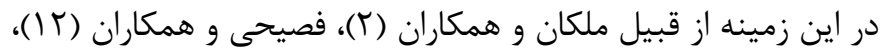

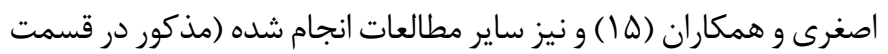

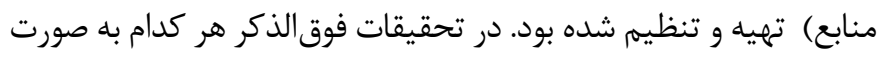

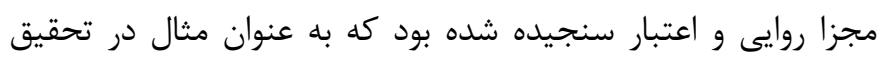

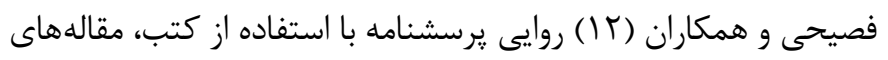

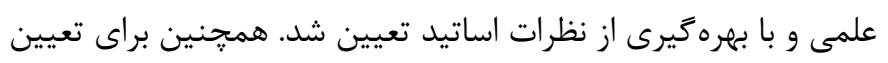

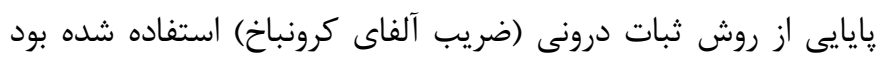

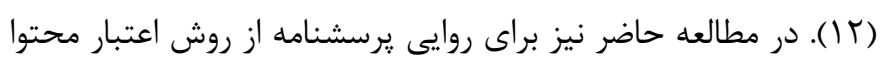

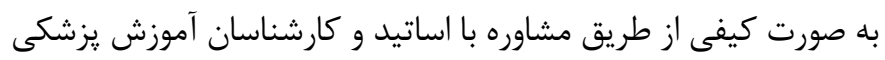

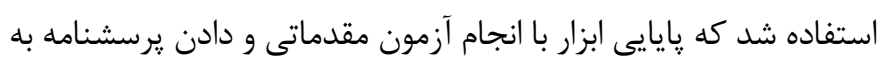

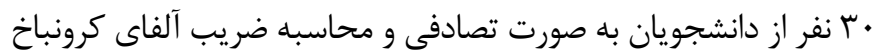

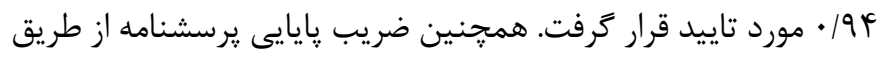

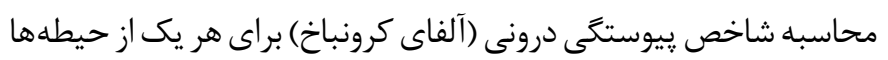

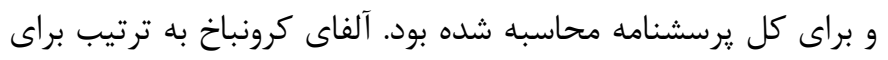

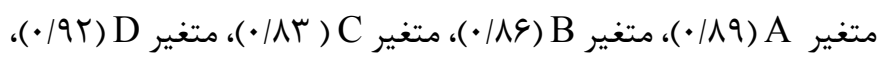

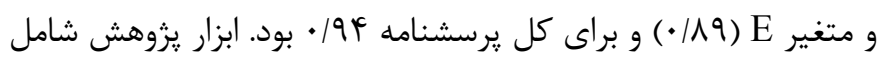
دو بخش كلى بود. بخش اول شامل اطلاعات جمعيتشناختى همجيجون جنس، رشته تحصيلى، مقطع تحصيلى، تعداد واحدهاى كذرانيده و معدل

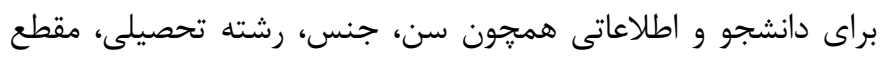

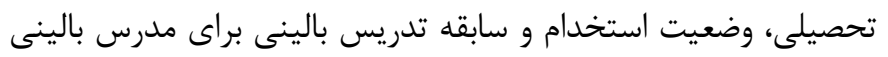

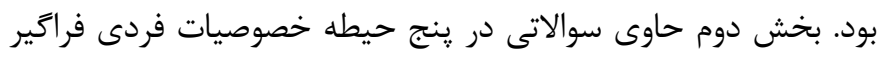

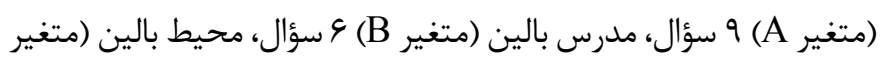

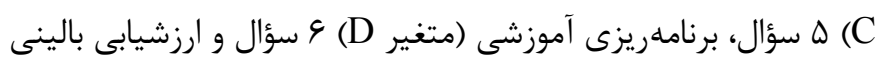

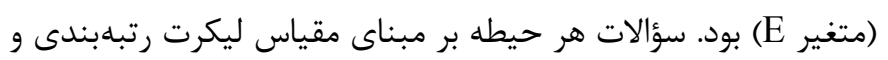

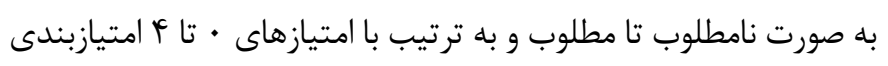

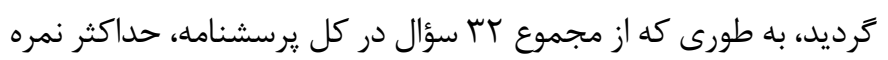

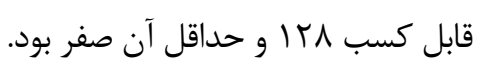

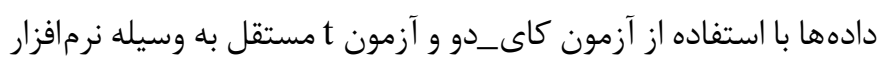
SPSS-18

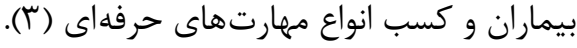

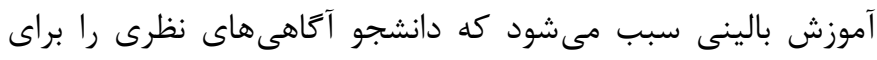

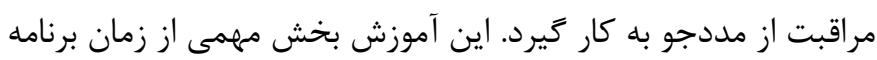

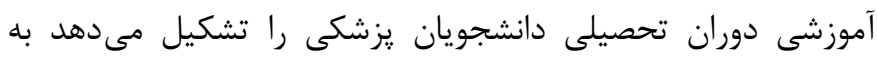

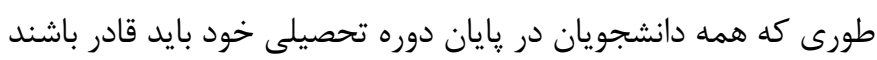

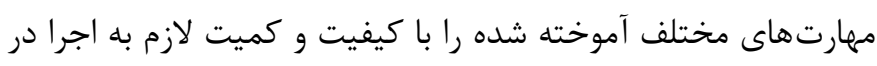

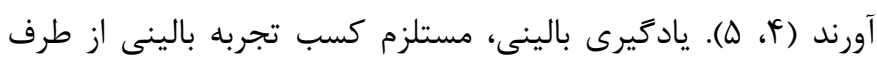

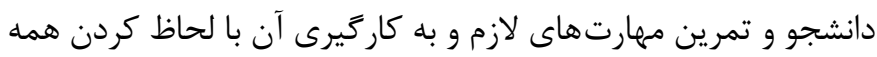

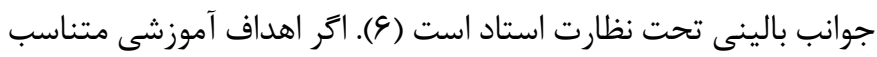
با نياز دانشجويان با تاكيد بر درك خودكارآمدى دانشجو باشد مى تواند

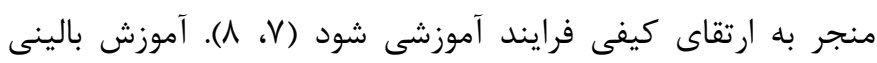

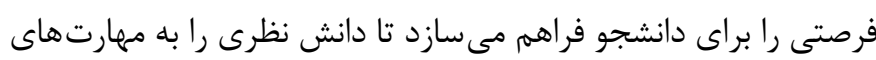

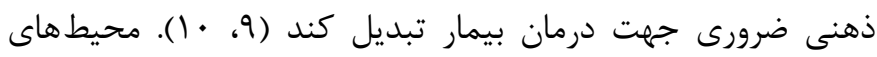

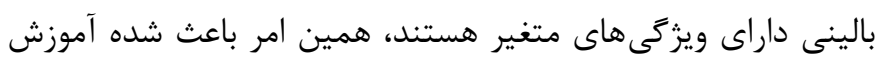

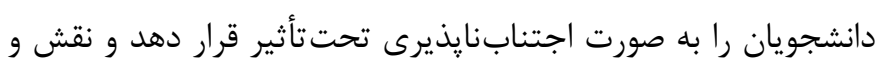

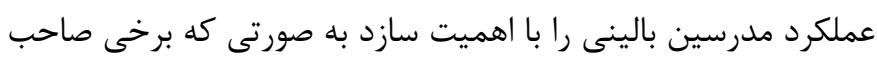

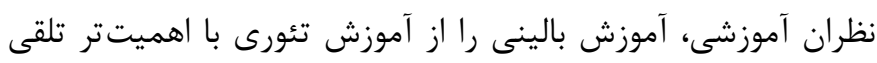

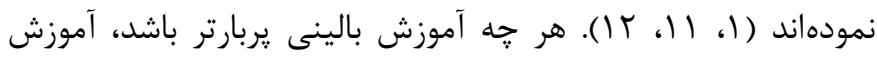

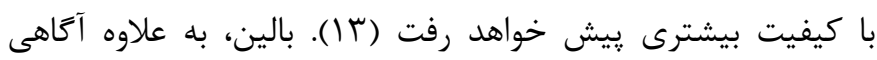

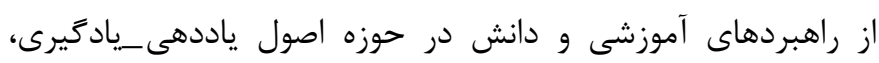

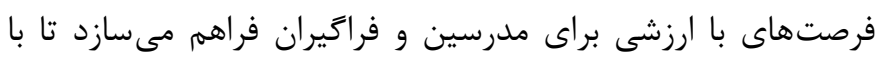

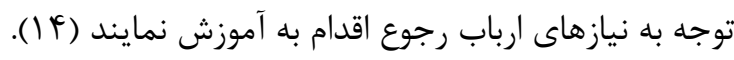

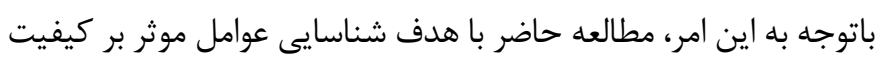

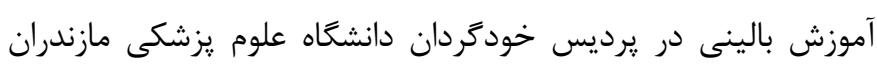

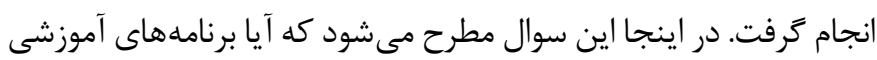

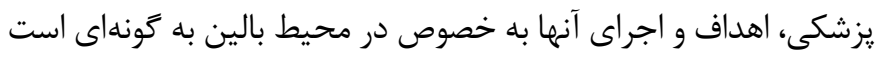

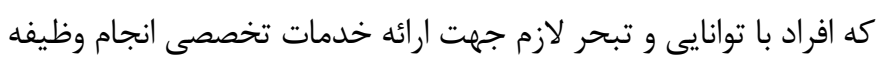

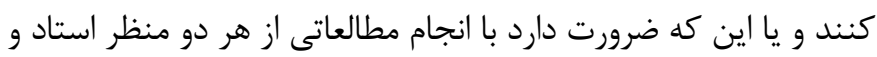
دانشجو مشكلات را شناسايى و تغييرات لازم ايجاد شود.

\section{روش كار}

اين يزوهش يك مطالعه توصيفى مقطعى بود كه بر روى || || نمونه

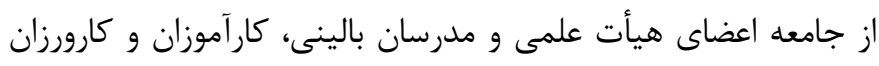

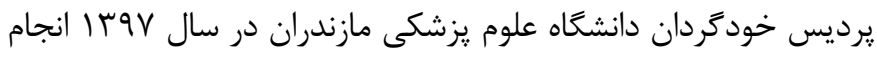

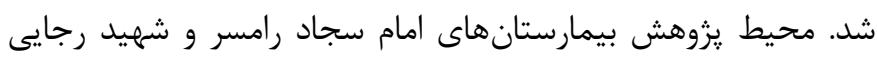

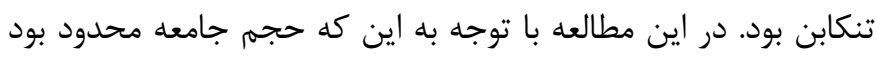

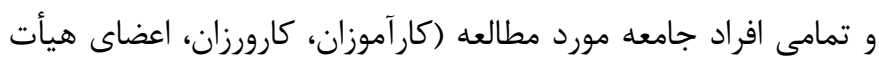




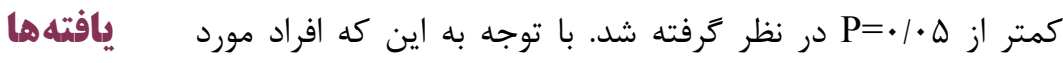

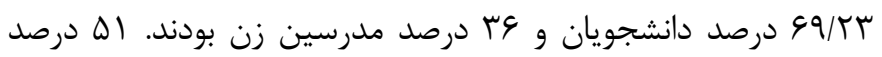
دانشجويان و •^ درصد مدرسين متاهل بودند. از ميان دانشجويان،

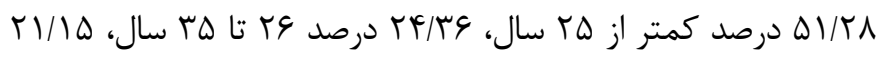

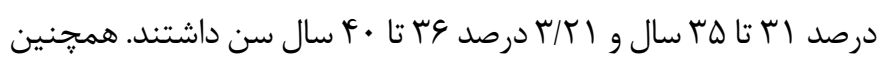

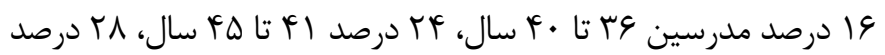

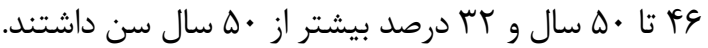

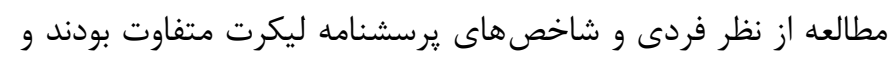

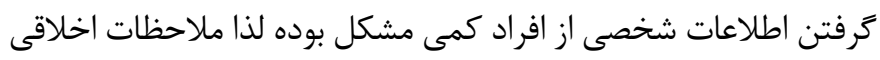

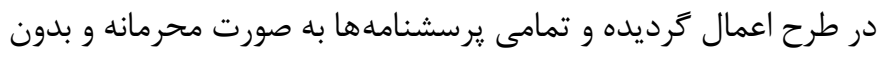

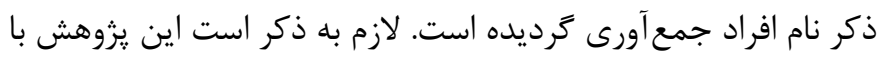
كد اخلاق IR.MAZUMS.REC.95.2644 در كميته اخلاق دانشخاه علوم يزشكى مازندران واحد رامسر بررسى و تصويب شده است.

جدول 1. شاخصهاى توصيفى متغيرهاى يزوهش

\begin{tabular}{|c|c|c|c|c|c|c|}
\hline بيشترين & كمترين - & انحراف معيار & 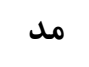 & 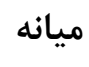 & ميانغين & متغيرها \\
\hline$\Delta$ & $1 / \pi r$ & $\cdot 119$ & r & r & $r / l$. & خصوصيات فردى فراتير \\
\hline$\Delta$ & 1 & $\cdot / \mathrm{NI}$ & $r / / V$ & r & t/9T & خصوصيات فردى مدرس \\
\hline$\Delta$ & 1 & $1 / 11$ & r & $r / r$. & $r / \cdot 9$ & محيط بالينى \\
\hline$\Delta$ & 1 & .199 & r & r & $r / 1 \Lambda$ & برنامهريزى آموزشى \\
\hline$\Delta$ & 1 & $\cdot / 1 \Delta$ & r & r & $r / I V$ & ارزشيابى بالينى \\
\hline$F / \Delta \Lambda$ & $1 / \Delta \Lambda$ &.$/ 09$ & $r / 9 \Lambda$ & $r / \cdot 1$ & $r / \cdot 9$ & كيفيت آموزش بالينى (كل يرسشنامه) \\
\hline
\end{tabular}

برابرى رد شده و اگر ميانكَين متغير كمتر از ب باشد، يعنى اينكه وضعيت

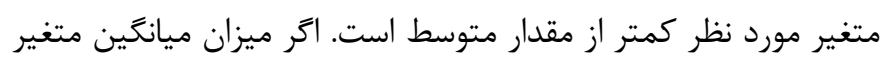

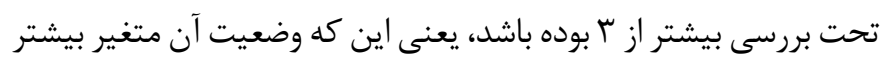

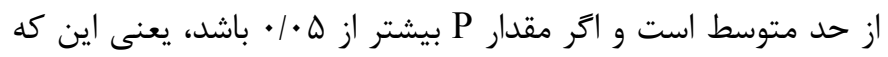
وضعيت متغير مورد نظر در حد متوسط است (جدول ؟).
براى بررسى وضعيت متغيرهاى يزوهش، از آزمون t تك نمونهاى استفاده

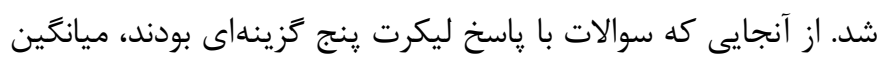

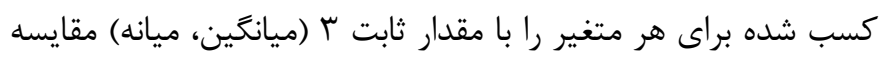

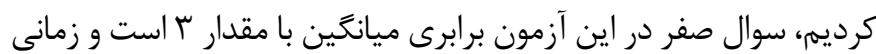
كه مقدار t محاسباتى بزرى و يا مقدار P كوجكتر از هـ • • باشد، سوال

جدول r. شاخصهاى كرايش مركزى، براكندَى و آزمون t مستقل

\begin{tabular}{|c|c|c|c|c|c|c|c|}
\hline \multirow[b]{2}{*}{ وضعيت } & \multirow[b]{2}{*}{$\mathbf{P}$} & \multicolumn{5}{|c|}{ مقدار ثابت مورد آزمون r } & \multirow[t]{2}{*}{ متغير ها } \\
\hline & & مقدار & Df & $\mathbf{t}$ & انحراف & ميانغين & \\
\hline 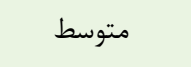 & $\mathrm{P}=\cdot / \cdot \Delta$ & $.|| r F \mid$ & $1 \wedge$ & $1 / \Delta \Delta$ & $\cdot / 19$ & $r / l \cdot$ & خصوصيات فردى فراتير \\
\hline 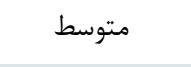 & $\mathrm{P}=\cdot 1 \cdot \Delta$ & $\cdot / / r M$ & 11 & $-1 / \Delta r$ & $\cdot / \mathrm{VI}$ & t/qT & خصوصيات فردى مدرس \\
\hline 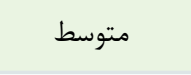 & $\mathrm{P}=\cdot / \cdot \Delta$ & $\cdot / r q \cdot r$ & $1 \wedge$ & $1 / .9$ & $1 / 11$ & $r / .9$ & محيط بالينى \\
\hline بيشتر از متوسط & $\mathrm{P}=\cdot \cdot \cdot \Delta$ & $.1 \cdot 14 \mathrm{~V}$ & $1 \wedge$. & $r / 4 q$ &.$/ 99$ & $r / M \Lambda$ & برنامهريزى آموزشى \\
\hline بيشتر از متوسط & $\mathrm{P}=\cdot / \cdot \Delta$ & $\cdot / \cdot \vee \wedge$ & 11 & $r / 99$ & $\cdot / 1 \Delta \Delta$ & $r / M V$ & ارزشيابى بالينى \\
\hline بيشتر از متوسط & $\mathrm{P}=\cdot / \cdot \Delta$ & 童. & 11. & $r / \cdot \Lambda$ & .109 & $r / .9$ & كيفيت آموزش بالينى (كل پرسشنامه) \\
\hline
\end{tabular}


دانشجو از سوى مسئولين بخشها، در متغير D به مولفههاى وجود برنامه

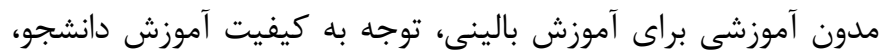

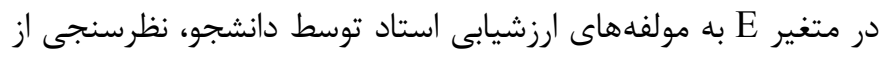

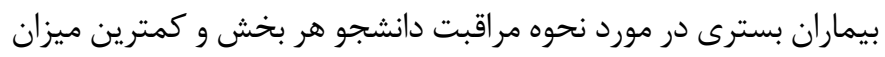

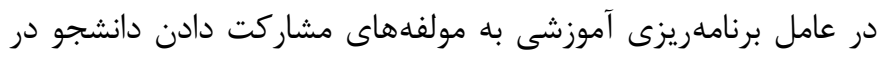

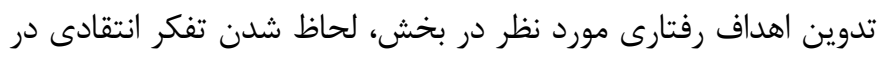
محتواى آموزشى (تئورى و كاربردى بالين)، وجود برنامه آموزش مدون در دانشكده و درخصوصيات فردى مدرس بالينى به مولفههاى بصيرت در كار بالينى، ابتكارعمل اختصاص يافت. بيشترين ميزان تاثير از نظر اساتيد بالينى در متغير A به مولفه هاى علاقه به رشته، علاقه به آموزش بالينى،

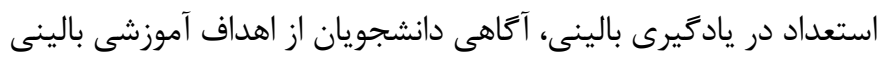

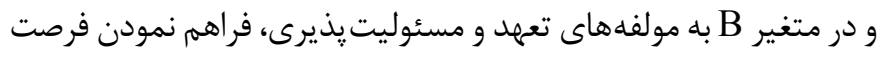

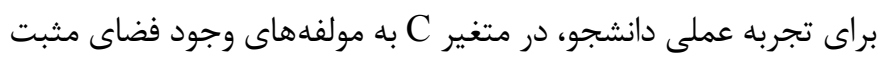

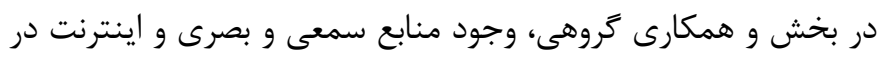

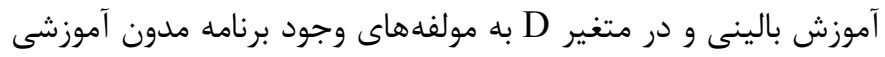
براى آموزش بالينى، توجه به كيفيت آموزش دانشجو و در متغير E به مولفههاى نظرسنجى از بيماران بسترى در مورد نحوه مراقبت دانشجو هر بخش، نظرسنجى منظهم از مدرسين و دانشجويان در دستيابى به اهداف آموزشى، نظرسنجى از كاركنان بخش در مورد نحوه همكارى

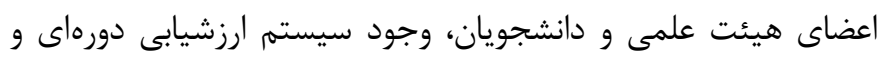

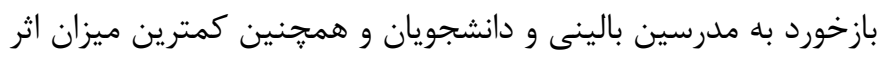

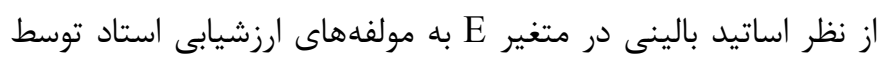

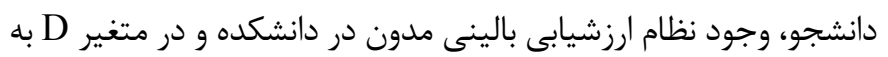

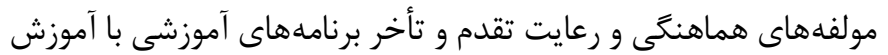
بالينى، وجود برنامه آموزش مدون در دانشكده و در متغير B به مولفه

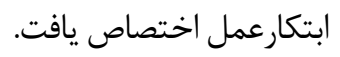

بحث نتايج مطالعه حاكى از آن بود كه از نظر دانشجويان، مولفه هاى علاقه به رشته، تعهد و مسئوليت يذيرى، وجود فضاى مثبت در بخش و همكارى

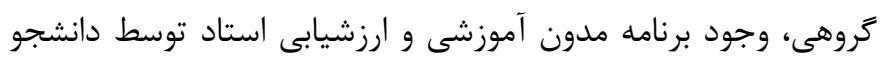

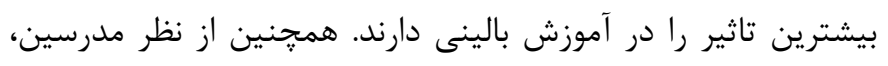

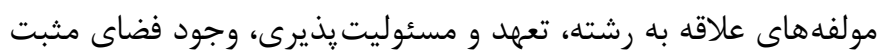
در بخش و همكارى تروهى، وجود برنامه مدون آموزشى و نظرسنجى از بيماران بسترى بيشترين تاثير را در آموزش بالينى دارند. در مطالعه حاضر شباهت عمده ديدگاه اساتيد و دانشجويان به شرح

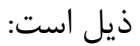

در اين بخش به بررسى سوالهاى يزوهش يرداخته شد و با استفاده

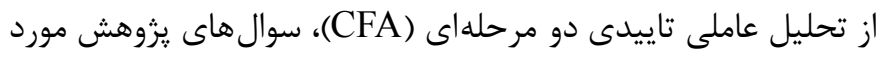

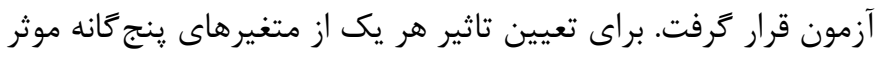

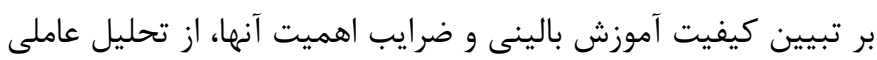

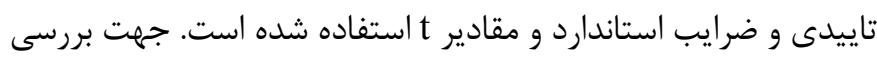
كفايت مدل نيز از شاخصهاى كاى_دو، شاخص برازش هنجار شده، شاخص برازش تطبيقى، شاخص نيكويى برازش، ريشه مربعات خطاى

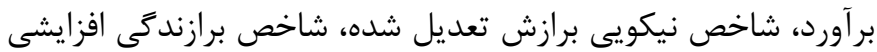
و شاخص برازش هنجار نشده استفاده شد. همانطور كه مى دانيم هدف اصلى اين بخش از يزوهش، بررسى ميزان

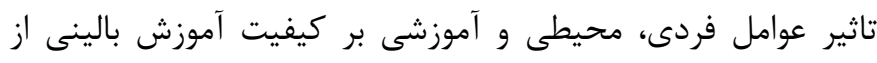

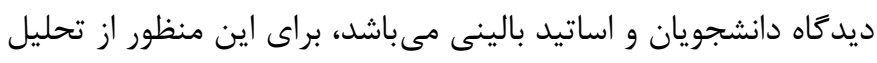
عاملى تاييدى استفاده شد. در بررسى حيطه خصوصيات فردى فراگير (A)؛ آزمون t مستقل نشان

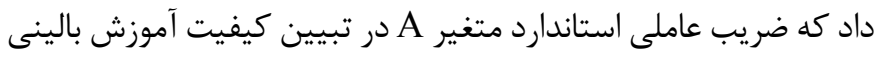

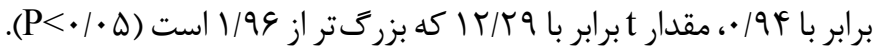

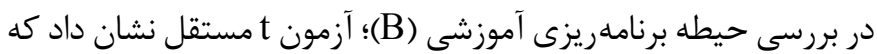
ضريب عاملى استاندارد متغير B در تبيين كيفيت آموزش بالينى برابر

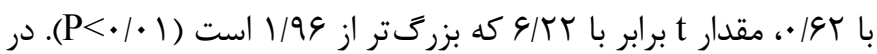
بررسى حيطه خصوصيات فردى مدرس بالينى (C)؛ آزمون t 1 مستقل

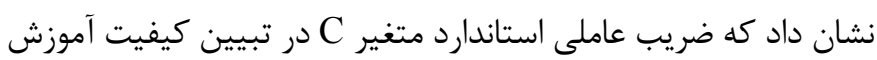

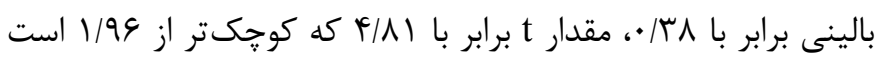

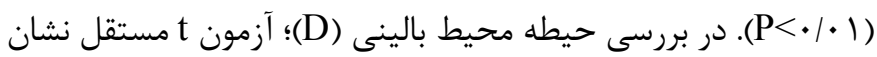

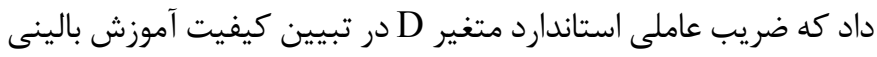

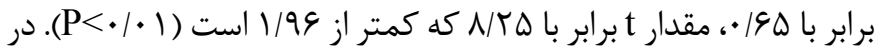
بررسى حيطه ارزيابى آموزش بالينى (E)؛ آزمون t مستقل نشان داد كه ضريب عاملى استاندارد متغير E در تبيين كيفيت آموزش بالينى برابر المرني

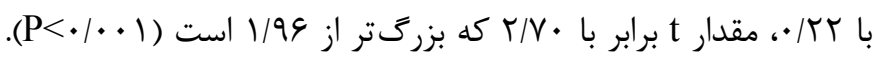

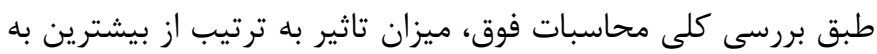
كمتر ين به شرح زير است: خصوصيات فردى فراگير (A)، برنامهريزى آموزشى (B)، خدريت خصوصيات

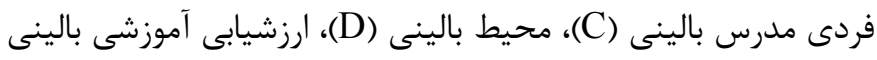

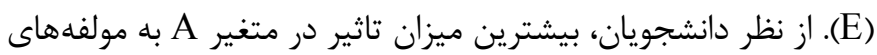

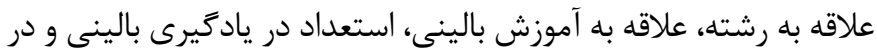
متغير B به مولفههاى تعهد و مسئوليتيذيرى، فراهم نمودن فرصت براى تجربه عملى دانشجو، رعايت زمان و وقتشناسى، در متغير Cبه مولفههاى

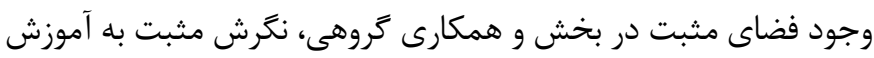


به كيفيت آموزش دانشجو، نظرسنجى از بيماران بسترى در مورد نحوه

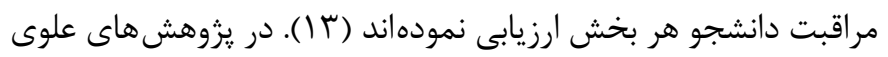
و عابدى (r) و Ironside ( • (r) همانند اين مطالعه از نظر دانشجويان و اساتيد بالينى، كمترين ميزان فراوانى و تاثير را در متغير D به مولفه وجود برنامه آموزش مدون در دانشكده (•(Y) و در متغير B به مولفه ابتكارعمل اختصاص دادند (r). نتايج حاصل از اين مطالعه نشان مىدهد خصوصيات فردى مدرس آنس در تبيين كيفيت آموزش بالينى تاثيرگذار مىباشد. شايان ذكر است كه اقداماتى از قبيل استفاده از مربيان مجرب، سهيم نمودن يرسنل بهداشتى و درمانى در آموزش دانشجويان و ايجاد انخيزه و مسئوليت آنان براى شركت در آموزش دانشجويان، فراهم كردن تجهيزات لازم در محيط بالينى براى يياده كردن اصول يراتيك در بالين و ارائه مراقبتهاى علمى و صحيح از بيمار و همجنين آموزشى نمودن هر جه بيشتر محيطهاى آموزشى فعلى، طراحى يك معيار ارشيابى دقيق، عينى و به دور از قضاوت شخصى براى سنجش مهارتهاى علمى و عملى دانشجويان براى اصلاح شرايط كنونى ثيشنهاد مىشود. به نظر مىرسد اجراى فرايند ياددهى مىتواند دانشجويان را قادر سازد تا حداكثر استفاده مطلوب را از توانايى هاى خود ببرند. متخصصان معتقدند كه مربيان بالينى تاثير شخرفى در افزايش كيفيت آموزش بالينى دارند و

مى توانند تجارب بالينى را براى دانشجويان سهل كند (V). در اين مطالعه ارتباط معنادارى بين محيط بالينى و كيفيت آموزش بالينى وجود داشت كه در مطالعات ديخر نيز به اين ارتباط اشاره شده است. همجنين ززارش شده امكانات محيط آموزشى، همكارى يرسنل و نيز برنامه و محتواى آموزش بالينى با بالاترين ميزان فراوانى و تاثير همراه بود ( (Y). نتايج تحقيق Papp و همكاران نشان داد دانشجويان زمانى محيط آموزشى را مناسب ارزيابى مى كنند كه ارتباط خوبى بين يرسنل وجود داشته و دانشجويان به عنوان يك همكار جوان مورد يذيرش قرار گيرند، به آنان احترام گذاشته شود و فرصت مناسبى را براى يادگيرى و دستيابى اهداف به آنها داده شود (Tr). لذا توصيه مىشود كه به اين مقوله توجه بيشترى گردد. محيط يادگيرى دانشجويان تركيبى روانشناسانه است كه شامل عواملشناختى، فرهنگى، اجتماعى، روانىعاطفى و انخيزشى است كه از طريق آن مدرسان و دانشجويان با يكديگر كار مى كنند بنابراين آنجه كه بايد در ابتداى امر مورد توجه قرار گيرد فراهم كردن محيطى با عناصر سالم مى باشد (II). توصيه مى شود كه همكارى با دانشجويان از سوى كار كنان بخش به عنوان يك معيار ارزشيابى سالانه يرسنل در نظر گرفته شود. از سوى ديخر مربيان

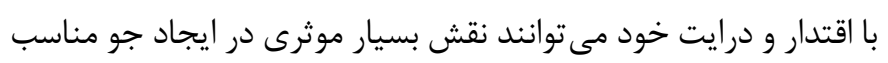

هر دو ₹روه بيشترين ميزان تاثير را در متغير A به مولفههاى علاقه به رشته، علاقه به آموزش بالينى و استعداد در يادگيرى بالينى، در متغير B به مولفه هاى تعهد و مسئوليت يذيرى و فراهم نمودن فرصت براى تجربه عملى دانشجو، در متغير C به مولفه وجود فضاى مثبت در بخش و همكارى گروهى، در متغير D به مولفه هاى وجود برنامه مدون آموزشى براى آموزش بالينى و توجه به كيفيت آموزش دانشجو، در متغير E به مولفه نظرسنجى از بيماران بسترى در مورد نحوه مراقبت دانشجو هر بخش اختصاص دادند. در يزوهش حاضر تفاوت عمده ديدگاه اساتيد و دانشجويان به شرح

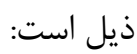
از نظر دانشجويان، بيشترين ميزان تاثير در متغير B به مولفه رعايت زمان و وقتشناسى، در متغير C به مولفه نخرش مثبت به آموزش دانشجو از سوى مسئولين بخشها، در متغير E به مولفه ارزشيابى استاد توسط دانشجو و كمترين ميزان تاثير در متغير D به مولفه مشاركت دادن دانشجو در تدوين اهداف رفتارى مورد نظر در بخش، لحاظ شدن تفكر انتقادى در محتواى آموزشى تئورى و كاربردى بالين و در متغير B به مولفه بصيرت در كار بالينى اختصاص يافت در حالى كه از نظر اساتيد بالينى بالاترين ميزان تاثير در متغير A به مولفه آتاهي داهي دانشجويان از اهداف آموزشى بالينى، در متغير C به مولفه وجود منابع سمعى و بصرى و اينترنت در آموزش بالينى و در متغير E به مولفههاى نظرسنجى منظم از مدرسين و دانشجويان در دستيابى به اهداف آموزش، نظرسنجى از كاركنان بخش در مورد نحوه همكارى اعضاى هيات علمى و دانشجويان، وجود سيستم ارزشيابى دورهاى و بازخورد به به نه مدرسين بالينى و دانشجويان و همجنين كمترين ميزان اثر در متغير

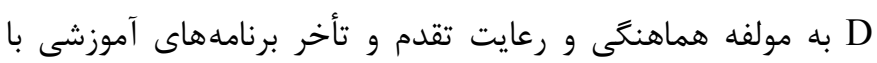
آموزش بالينى اختصاص يافت. در يروهش هاى وهابى و همكاران (r I ) و فصيحى و همكاران (T) همانند اين مطالعه نظر دانشجويان در مورد لزوم بازنگرى و تطابق هر جه بيشتر روشهاى ارزشيابى به كار رفته

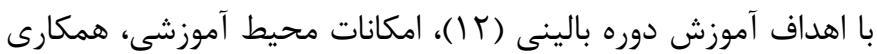
يرسنل و نيز برنامه و محتواى آموزش بالينى با بالاترين ميزان فراوانى و تاثير همراه بود (r|). در مطالعات طبرى و همكاران (1))، ملكان و همكاران (r) و Sand-Jecklin (19) همانند اين مطالعه از نظر دانشجويان و اساتيد بالينى بيشترين ميزان تاثير را در مولفههاى علاقه

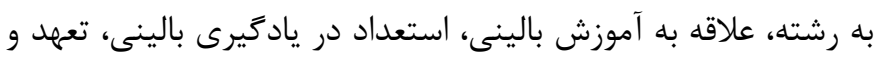
مسئوليت يذيرى (ץ)، فراهم نمودن فرصت براى تجربه عملى دانشجو، وجود فضاى مثبت در بخش و همكارى گروهى بين مدرس، دانشجو و كاركنان (9 ()، وجود برنامه مدون آموزشى براى آموزش بالين، توجه 
دانشجويان و نيز اعمال كنترل بر عملكرد آنها در يادگيرى بالينى از سوى

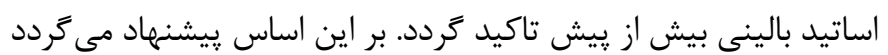
در مطالعات آينده به عواملى از جمله ارزيابى هاى مكرر عرصههاى بالينى و مقايسه وضعيت موجود با وضعيت قبل و يا بعد، شناسايى نقاط ضعف و قوت مؤثر در آموزش بالينى بيشتر توجه شود.

\section{تشكر و قنرواذى}

اين مقاله بركرفته از يايان نامه دوره دكتراى حرفهاى يزشكى دفاع شده در دانشكده يزشكى يرديس خودگردان رامسر استخراج شده است. نويسندكان بر خود لازم ميى انند مراتب تشكر صميمانه خود را از

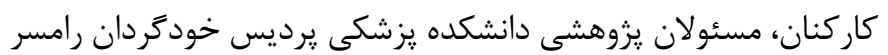
به دليل حمايت مالى و هيات داوران :اياننامه كه ما را در انجام و ارتقاء كيفى اين يزوهش يارى دادند، اعلام نمايند.

\section{References}

1. Rahimi A, Ahmadi F. The obstacles and improving strategies of clinical education from the viewpoints of clinical instructors in Tehran's Nursing Schools. Iranian Journal of Medical Education. 2005;5(2):73-80. (Persian)

2. Malakan Rad E, Einollahi B, Hosseini S, Momtaz Manesh N. Clinical teaching and assessment: What every clinical teacher must know. 1st ed. Tehran:Tohfeh with Boshra Publications;2006. pp. 1-40. (Persian)

3. Alavi M, Abedi H. Nursing students' experiences and perceptions of effective instructor in clinical education. Iranian Journal of Medical Education. 2008;7(2):325-334. (Persian)

4. Cox KR, Ewan CE. The medical teacher. London:Churchill Livingstone; 1988.

5. Azimi N, Bagheri R, Mousavi P, Bakhshandeh-Bavrsad M, Honarjoo M. The study of clinical education problems and presenting solutions for improvement its quality in midwifery. Research in Medical Education. 2017;8(4):43-51. (Persian)

6. Dent J, Harden RM, Hunt D. A practical guide for medical teachers. $5^{\text {th }}$ ed. Amsterdam:Elsevier Health Sciences;2017.
براى همكارى با دانشجويان از سوى يرسنل فراهم نمايند (9 (1). از جمله محدوديتهاى اين مطالعه عدم استفاده از نظرات دانشجويانى بود كه به تازگى فارغالتحصيل شدهاند بود كه در يزوشهاى آينده اميدواريم نظرات اين عزيزان نيز در قالب يرسشنامه در نتايج گنجانده شود.

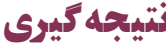

بر مبناى نتايج مطالعه جنين به نظر مىرسد كه تقويت و اجرا منظمم برنامههاى موجود و همجنين ايجاد محيط آموزشى استاندارد مى تواند بر افزايش كيفيت آموزش بالينى بيافزايد. همجنين علاوه بر توجه به مولفه هاى مورد مطالعه، بايد بر اصول ديخرى همجِون تعيين دقيق تجارب يادگيرى، به كارگيرى روشهاى آموزشى مناسب، انجام ارزيابىهاى مورئ تكوينى به طور مستمر، استفاده از محيطهاى شبيهسازى شده و مكانهاى آموزشى متناسب با شرايط كارى، ارتقا سطح انخَيزش، حمايت

7. Sahebazamani M, Salahshorian Fard A, Akbarzadeh A, Mohammadian R. Comparison the viewpoint of nursing students and their trainers regarding preventing and facilitating factors of effective clinical teaching in Islamic Azad University, Marageh branch. Medical Sciences Journal of Islamic Azad University, Tehran Medical Branch. 2011;21(1):38-43. (Persian)

8. Tahmasebi M, Adibi P, Zare-Farashbandi F, Taheri A, Papi A, Rahimi A. Medical students's satisfaction of clinical informationist educational program. Iranian Journal of Medical Education. 2019;19:385-393. (Persian)

9. Esmaeili M, Hozni S, Mosazadeh B, Zavareh A. Good teacher's characteristics and its influence on dental students academic motivation in guilan university of medical sciences. Research in Medical Education. 2017;9(3):10-18. (Persian) 10. Nadi F, Nadi E, Ahmadinia H. The status of implementing medical student's clinical training programs in different departments at Shahid Beheshti Hospital of Hamadan University of Medical Sciences. Development Strategies in Medical Education. 2019;6(2):63-74. (Persian) 
11. Zolfahari SH, Bijari B. Medical students' perspective of clinical educational environment of hospitals affiliated with Birjand University of Medical Sciences, Based on DREEM model. Journal of Birjand University of Medical Sciences. 2015;22(4):368-375. (Persian)

12. Fasihi HT, Soltani Arabshahi S, Tahami S, Mohammad Alizadeh S. Viewpoints of medical students about the quality of clinical education. The Journal of Qazvin University of Medical Sciences. 2004;8(1):4-9. (Persian)

13. Vahabi S, Ebadi A, Rahmani R, Tavallaei A, Khatouni A, Tadrisi S, et al. Comparison of the status of clinical education in the views of nursing educators and students. Education Strategies in Medical Sciences. 2011;3(4):179-182. (Persian)

14. Naderi N, Rezaei P. Comparison of Bandar Abbas Medical School's educational environment before and after the implementing an integrated physiopathology curriculum: Students' viewpoints. Iranian Journal of Medical Education. 2014;13(10):851-859. (Persian)

15. Asghari M, Rafieepour A, Shahedi S, Mirzahoseini M, Chavooshi M, Abbassinia M. Assessment criteria of effective teaching of expert teachers based on occupational health students' viewpoints in Tehran University of Medical Sciences. Archives of Advances in Biosciences. 2016;7(2):29-34.

16. Elcigil A, Sarı HY. Determining problems experienced by student nurses in their work with clinical educators in Turkey. Nurse Education Today. 2007;27(5):491-498.

17. Shipman D, Roa M, Hooten J, Wang ZJ. Using the analytic rubric as an evaluation tool in nursing education: The positive and the negative. Nurse Education Today. 2012;32(3):246-249. 18. Tabari F, Ebadi A, Jalalinia S. Pathology of the clinical education of medical-surgical nursing courses: A qualitative study. Education Strategies in Medical Sciences. 2014;6(4):209-215. (Persian)

19. Sand-Jecklin K. Assessing nursing student perceptions of the clinical learning environment: Refinement and testing of the SECEE inventory. Journal of Nursing Measurement. 2009;17(3):232-246.

20. Ironside PM, McNelis AM. Clinical education in prelicensure nursing programs: Findings from a national survey. Nursing Education Perspectives. 2010;31(4):264-265.

21. Kebriaei A, Roudbari M, Rakhshani NM, Mirlotfi P. Assessing quality of educational services at Zahedan University of Medical Sciences. Zahedan Journal of Research in Medical Sciences. 2005;7(2):139-146. (Persian)

22. Moulding NT, Silagy C, Weller D. A framework for effective management of change in clinical practice: Dissemination and implementation of clinical practice guidelines. BMJ Quality \& Safety. 1999;8(3):177-183. 